Original Research Paper

\title{
Eimeria Legionensis and Eimeria kofoidi (Apicomplexa: Eimeriidae) Infection and Associated Lesions in Naturally Infected Red-Legged Partridges (Alectoris rufa)
}

\author{
${ }^{1}$ G. Fichi, ${ }^{2}$ G. Rossi and ${ }^{1}$ Stefania Perrucci \\ ${ }^{1}$ Dipartimento di Scienze Veterinarie, University of Pisa, \\ Viale delle Piagge 2, 56124, Pisa, Italy \\ ${ }^{2}$ Scuola di Bioscienze e Medicina Veterinaria \\ University of Camerino. Via Circonvallazione 93-95, 62024 Matelica, Italy
}

Article history

Received: 27-06-2017

Revised: 25-09-2017

Accepted: 9-11-2017

Corresponding Author: Stefania Perrucci Department of Veterinary Sciences, University of Pisa, Viale delle Piagge 2, 56124, Pisa, Italy,

Tel. +390502216949 ,

Fax +39050 2210654,

Email: stefania.perrucci@unipi.it

\begin{abstract}
With the aim to identify the Eimeria species responsible for coccidiosis in 50 deceased red-legged partridges (Alectoris rufa), individual faecal samples were collected, dissolved in $2.5 \% \mathrm{~K}_{2} \mathrm{Cr}_{2} \mathrm{O}_{7}$ solution and maintained at room temperature to allow sporulation of the oocysts. Morphology and dimensions of sporulated oocysts were microscopically evaluated. To assess Eimeria intestinal localisation, faecal samples and scrapings taken from the different intestinal segments of each deceased animal were examined by fresh smears and flotation test, while the intestines were examined for gross lesions, then fixed in $10 \%$ formalin and processed for histopathological analysis. From scrapings and morphological analysis, Eimeria kofoidi and Eimeria legionensis were identified in the small intestine and in the caecum and colon, respectively. Histopathological analysis confirmed the presence of two distinct Eimeria species. In particular, E. kofoidi macrogamonts were found in epithelial cells of jejunum and ileum, between the basal lamina and the nucleus of the infected intestinal cells. This latter was flattened and displaced above. E. legionensis macrogamonts were instead found localised between the nucleus and the luminal surface of the infected caeca and colonic cells and these macrogamonts were larger than those of E. kofoidi. Chronic enteritis and severe displacement of the deep crypts of the small intestine, large areas of caeca and colonic epithelial necrosis associated to thickened wall and mononuclear cells infiltration diffused in a transmural manner, were the main histopathological lesions.
\end{abstract}

Keywords: Eimeria Kofoidi, Eimeria Legionensis, Intestinal Lesions, Intestinal Localisation, Alectoris Rufa

\section{Introduction}

Among Galliformes, the red-legged partridge (Alectoris rufa) is an important phasianid game bird species (Birkan and Jacob, 1988) native to the Iberian Peninsula, but currently presents also in Italy (Millan, 2009; Naciri et al., 2011). Among birds of the genus Alectoris, coccidiosis is a disease caused by intracellular intestinal protozoans of the genus Eimeria (Apicomplexa: Eimeriidae). Coccidiosis is prevalent in game farms and often responsible for diarrhoea, weight loss, poor feed conversion and for mortality of infected birds (Pellérdy, 1974; Reck and McQuistion, 1994). Clinical disease or even epidemic- like outbreaks with considerable mortality are frequently observed in game farms (Bolognesi et al., 2006; Naciri et al., 2011), especially when birds are reared on the floor and kept in confined pens that favour the spread of coccidian infections. Although coccidiosis of the red-legged partridge is known from a long time (Pellérdy, 1974; Levine, 1988; Duszynski et al., 2000; Bolognesi et al., 2006; Naciri et al., 2011), few data are available on histopathological lesions caused by Eimeria species infecting $A$. rufa and on the histological localisation of these species.

This study was aimed to assess Eimeria species and associated lesions in naturally infected and deceased A. rufa, reared for their releasing in the natural habitat. 


\section{Materials and Methods}

\section{Animals}

Fifty deceased red-legged partridges (A. rufa) of about 30-40 days in age and from a farm located in Tuscany (central Italy), were examined. In this farm, birds are reared directly on the floor through their life and coccidiosis is frequently observed.

Examined birds had died after a coccidiosis outbreak with about $10 \%$ mortality.

\section{Parasitological and Gross Examination}

From each examined bird, rectal faecal samples were collected. An aliquot of each faecal sample was microscopically observed fresh and after flotation test, by using a low density solution (specific gravity 1.2 ). To allow sporulation of Eimeria oocysts, the remaining aliquots were dissolved in $2.5 \% \mathrm{~K}_{2} \mathrm{Cr}_{2} \mathrm{O}_{7}$ solution at $22^{\circ} \mathrm{C} \pm 1{ }^{\circ} \mathrm{C}$. After sporulation, oocysts, sporocysts and all other structures were microscopically evaluated at $400 \times$ and $1000 \times$ and measured by using a $10 \times$ eyes pie micrometer.

In order to evaluate the presence of gross lesions due to coccidiosis, at necropsy the intestines were removed and opened from the duodenum to the rectum. In addition, faecal contents and scrapings of intestinal mucosa taken from each intestinal segment, i.e. proximal and distal duodenal, jejunal and ileal tracts, caecum and recto-colic tracts, were microscopically evaluated as fresh samples and after flotation test, by using a low density solution (specific gravity 1.2). A faecal aliquot taken from each intestinal segment was also processed for sporulation and identification of the isolated oocysts, as described above.

\section{Histopathological Examination}

From all necropsied birds, the different intestinal segments were fixed in $10 \%$ buffered formalin and then paraffin embedded. Three micrometers thick sections were placed onto pre-treated slides (Bio-Optica, Milan, Italy) to promote adhesion, and dried overnight at $37^{\circ} \mathrm{C}$. After being de-waxed, sections were stained with hematoxylin-eosin (HE) for histopathological examination. All the histological samples were microscopically examined at $100 \mathrm{x}$ and $400 \mathrm{X}$ magnification to identify the intestinal segment/s infected by Eimeria species and to score coccidian infection as the mean number of parasites counted in up to 10 fields per section (100 cells counted per field) at 400X magnification (Perrucci et al., 2006).

Histopathological intestinal lesions were scored according to the Sydney System classification (Genta and Dixon, 1995). To this aim, the number of inflammatory cells found in the different intestinal compartments, i.e., villus, basal crypt area, villus-crypt junction of the small intestine and apical crypt area and basal crypt area of the large intestine, was microscopically quantified by using a $40 \times$ objective, a $10 \times$ eyepiece and a square eyepiece reticule $(10 \times 10$ squares, with a total area of $62,500 \mu \mathrm{m}^{2}$ ). Then, arithmetic means were calculated for ten $62,500 \mu \mathrm{m}^{2}$ sites of each intestinal region.

Histological criteria for normal gastrointestinal mucosa and wall included detection of none or only a few mononuclear cells interspersed throughout the corion, absence of lymphoid aggregates and none or only a few scattered neutrophils across the intestinal epithelium, per High-Power Field (HPF) (Rossi et al., 2015; Fronte et al., 2013).

Neutrophils were classified as absent (score 0 ) when there was none or only single sporadic cells, mild (score 1) for 5 to 10 cells, moderate (score 2) for 20 to 40 cells, marked (score 3 ) for 50 to 100 cells and severe (score 4) for 100 to 200 cells or more, per HPF. The number of mononuclear cells was considered to be normal (score 0 ) when none or only a few cells were seen among intestinal glands, mild (score 1) for 50 to 100 cells, moderate (score 2 ) for 100 to 200 cells, marked (score 3 ) for 200 to 600 cells and severe (score 4) for 600 cells or more), per HPF.

The number of lymphocyte aggregates was also counted and the status of "activation" of follicles of lymphocyte aggregates was scored by measuring the mean of the areas of 10 randomly selected follicles in each infected partridge.

\section{Results}

\section{Parasitological and Gross Examination}

After sporulation, all examined animals were found positive for Eimeria coccidian oocysts of two different morphology. From microscopically evaluation of oocysts found in faecal samples and in faecal contents and scrapings of each intestinal segment, the first type of oocysts $(n=1000)$ were found in the jejunum and ileum (Table 1). Gross lesions found in these intestinal tracts included the presence of mucus and erosions. Thickening of the wall of the posterior half of the small intestine was also observed.

Oocysts found in these intestinal segments are oval in shape and measure $17.60 \mu \mathrm{m} \times 13.26 \mu \mathrm{m}$ in size (14.04$19.50 \mu \mathrm{m} \times 11.56-14.82 \mu \mathrm{m})$, with a length/width ratio of 1.33 (1.00-1.91). No residuum was present, but one or more polar granules were present in mature oocysts. The almond-shaped sporocysts measure $8.46 \mu \mathrm{m} \times 6.00$ $\mu \mathrm{m} \quad(6.24-10.92 \mu \mathrm{m} \times 4.68-7.80 \mu \mathrm{m})$ with $\mathrm{a}$ length/width ratio of $1.41(1.00-2.00)$ and show a granular residuum and a small Stieda body (Fig. 1A). Because of these features and of intestinal localisation, these oocysts were identified with Eimeria kofoidi (Table 2). 


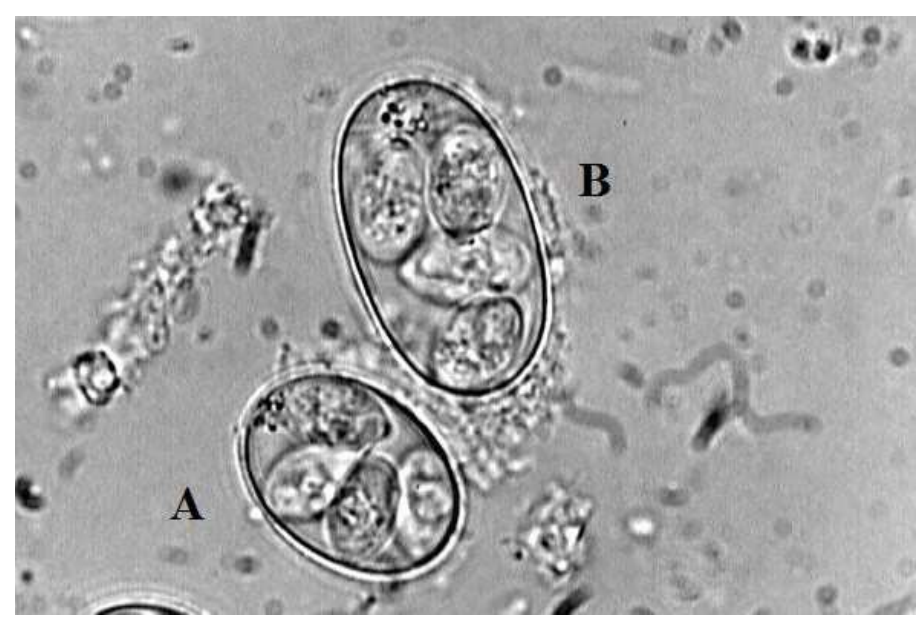

Fig. 1: (A) Eimeria kofoidi sporulated oocyst (B) Eimeria legionensis sporulated oocyst

Table 1: Mean score ( \pm standard deviation) of infection intensity and of histopathological lesions found in the different intestinal segments of 50 deceased red-legged partridges (Alectoris rufa) infected by Eimeria kofoidi and Eimeria legionensis

\begin{tabular}{llll}
\hline Intestinal segment & Eimeria species & Infection Score* & Lesion Score** \\
\hline Duodenum & - & $0( \pm 0)$ & $0( \pm 0)$ \\
Jejunum & E. kofoidi & $1.4( \pm 0.50)$ & $1.2( \pm 0.75)$ \\
Ileum & E. kofoidi & $3( \pm 0)$ & $3.4( \pm 0.50)$ \\
Caecum & E. legionensis & $2.8( \pm 0.40)$ & $3.6( \pm 0.50)$ \\
Colon & E. legionensis & $1.8( \pm 0.48)$ & $0.8( \pm 0.40)$ \\
\hline
\end{tabular}

*Score: 0: no infected enterocytes; 1: $<20 \%$ of infected enterocytes; 2: 20\% - 40\% of infected enterocytes; 3: $>40 \%$ infected enterocytes** Mean of the scores found at histopathological examination for each type of inflammatory cells (lymphocytes and lymphocyte aggregates, macrophages and neutrophils) in ten areas of $62,500 \mu \mathrm{m}^{2}$ of each intestinal segment

Table 2: Comparison of Eimeria kofoidi and Eimeria legionensis oocyst morphology and dimensions (in $\mu \mathrm{m}$ ) and their intestinal localisation observed in 50 deceased red-legged partridges (Alectoris rufa) examined in the present study, with those reported in previous studies from the same bird host

\begin{tabular}{|c|c|c|c|c|}
\hline Species & $\begin{array}{l}\text { Mature Oocysts } \\
\text { Morphology and } \\
\text { dimensions (range) }\end{array}$ & $\begin{array}{l}\text { Sporocysts } \\
\text { Morphology and mean } \\
\text { mean dimensions (range) }\end{array}$ & Localisation & References \\
\hline Eimeria & Oval; 1 or $2 \mathrm{PG}$ & Ovoid almond; R; SB & Jejunum and Ileum & Present Study \\
\hline \multirow[t]{9}{*}{ kofoidi } & $\begin{array}{l}17.60 \times 13.26 \\
(1404-1950 \times 1056-1482)\end{array}$ & $\begin{array}{l}8.46 \times 6.00 \\
(624-10.92 \times 4.68-780)\end{array}$ & & \\
\hline & Oval; $1 \mathrm{PG}$ & Elongated; R; SB & \multirow[t]{3}{*}{ Terminal Ileum and Caecum } & Lizcano Herrera and \\
\hline & $19 \times 13.3$ & $9.1 \times 5.2$ & & Romero Rodriguez (1972) \\
\hline & $(13.6-20.9 \times 7.6-15.2)$ & $(7.6-11.4 \times 4.7-7.6)$ & & \\
\hline & Rounded & Oval & \multirow[t]{2}{*}{${ }_{-}^{*}$} & \multirow[t]{2}{*}{ Bolognesi et al. (2006) } \\
\hline & $17.4 \times 14.91(16-19 \times 14-16)$ & $8.5 \times 5.5$ & & \\
\hline & Spherical/Broadly & & \multirow{3}{*}{$\begin{array}{l}\text { Small intestine, mainly in } \\
\text { the Duodenal loop and Jejunum }\end{array}$} & \\
\hline & Ovoid; 1,2 or more $\mathrm{PG}$ & Ovoid almond; SB & & \multirow[t]{2}{*}{ Naciri et al. (2011) } \\
\hline & $19.3-16.3(14.0-21.4 \times 12.0-19.5)$ & $9.4 \times 5.3$ & & \\
\hline \multirow{9}{*}{$\begin{array}{l}\text { Eimeria } \\
\text { legionensis }\end{array}$} & Elliptic; M & Almond-shaped; R; SB & \multirow[t]{3}{*}{ Caecum and Colon } & \multirow[t]{3}{*}{ Present Study } \\
\hline & $22.58 \times 15.12$ & $9.95 \times 6.31$ & & \\
\hline & $\begin{array}{l}(15.60-27.30 \times 12.48-17.94) \\
\text { Elliptic, M }\end{array}$ & $\begin{array}{l}(7.02-10.92 \times 4.68-7.02) \\
\text { Almond-shaped: R: SB }\end{array}$ & & \\
\hline & $21.3 \times 14.6(18-24 \times 12-16)$ & $9.5-10.6$ & Caecum & \multirow{2}{*}{$\begin{array}{l}\text { Cordero Del Campillo } \\
\text { and Hernàndez (1966) } \\
\text { Hernandez Rodriguez et al. } \\
\text { (1974) }\end{array}$} \\
\hline & $\overline{1} 8.5 \times 14.2$ & - & - & \\
\hline & Elliptic, M & Almond-shaped; SB & \multirow[t]{2}{*}{$-^{*}$} & \multirow[t]{2}{*}{ Bolognesi et al. (2006) } \\
\hline & $\begin{array}{l}22.0 \times 15.3 \\
(19-24 \times 13-16)\end{array}$ & $9.73 \times 5.56$ & & \\
\hline & Elliptic, M & Almond-shaped; R; SB & \multirow[t]{2}{*}{ Caecum } & \multirow[t]{2}{*}{ Naciri et al. (2011) } \\
\hline & $22.6 \times 14.9(18.6-26 \times 13-16.7)$ & $9.8 \times 6.2$ & & \\
\hline
\end{tabular}

*: Faecal cultures carried out on the whole intestinal content without distinguishing the different tracts, but macroscopic lesions were mostly found in the duodenum; PG: Polar Granules; R: granular Residuum; SB: Stieda Body; M: Micropyle 
The second species was found mainly in the caecum, but also in the colon (Table 1). Gross lesions in the large intestines included oedema, pinpoint hemorrhages and thickening, mainly of the caecal wall. These oocysts $(\mathrm{n}=1000)$ are elliptic and of $22.58 \mu \mathrm{m} \times 15.12 \mu \mathrm{m}(15.60-27.30 \mu \mathrm{m} \times 12.48-17.94$ $\mu \mathrm{m})$ in size, with a length/width ratio of 1.49 (1.111.94). No residuum appeared after sporulation, but a micropyle is visible in the oocyst wall. The sporocysts measure $9.95 \mu \mathrm{m} \times 6.31 \mu \mathrm{m}$ (7.02-10.92 $\mu \mathrm{m} \times 4.68$ $7.02 \mu \mathrm{m})$ with a length/width ratio of 1.58 (1.29$2.00)$. They contain a granular residuum and show an evident Stieda body at the pointed end (Fig. 1B). Based on their morphological and metrical features and intestinal localisation, these oocysts were identified with Eimeria legionensis (Table 2).

\section{Histopathological Examination}

Histopathological analysis confirmed that all examined birds were infected by two different Eimeria species. At histopathological analysis, jejunum, ileum, caecum and colon were the intestinal sites of coccidian localisation and lesions, although with various degrees of infection and lesion score (Table 1 and 3). In particular, lesions found in the small intestine were represented by chronic enteritis and mononuclear cells infiltration diffused in a transmural manner in the jejunal and ileal walls. The ileum was the site in which the higher degrees of infection and lesion scores were observed (Table 1 and 3). In some cases, a severe displacement of the deep crypts (Fig. 2) associated with the presence of a large number of different Eimeria life stages, indicating an active coccidian replication was evidenced. Among the different coccidian stages, macrogamonts observed in the crypts of the ileum and in the jejunum measured about 10.73 $\mu \mathrm{m}$ in diameter and were localised between the basal pole and the nucleus of the host cells. This particular localization contributed to the nuclear displacement (Fig. 3 ). Similar degree and patterns of mucosal inflammation, characterised by a transmural infiltration of mononuclear cells, were observed also in the colonic and caecal walls. Large areas of epithelial necrosis were found associated with the thickened wall. In examined birds, the caecum was the intestinal site where the highest degree of severity was scored for histopathological lesions (Table 1 and 3; Fig. 4). An extra-epithelial Eimeria localisation was also observed, mainly in the colon. In fact, in this intestinal segment free microgamonts, intra-macrophagic merozoites and several schizonts were found interspersed in the lamina propria. An opposite intraepithelial localization was observed for macrogamonts found in the caecal and colonic mucosa respect to those found in the small intestine. Indeed, they were located between the nucleus and the free pole of the host cells (Fig. 5). Moreover, these macrogamonts were larger (about $15.25 \mu \mathrm{m}$ in diameter) than those observed in the small intestine.

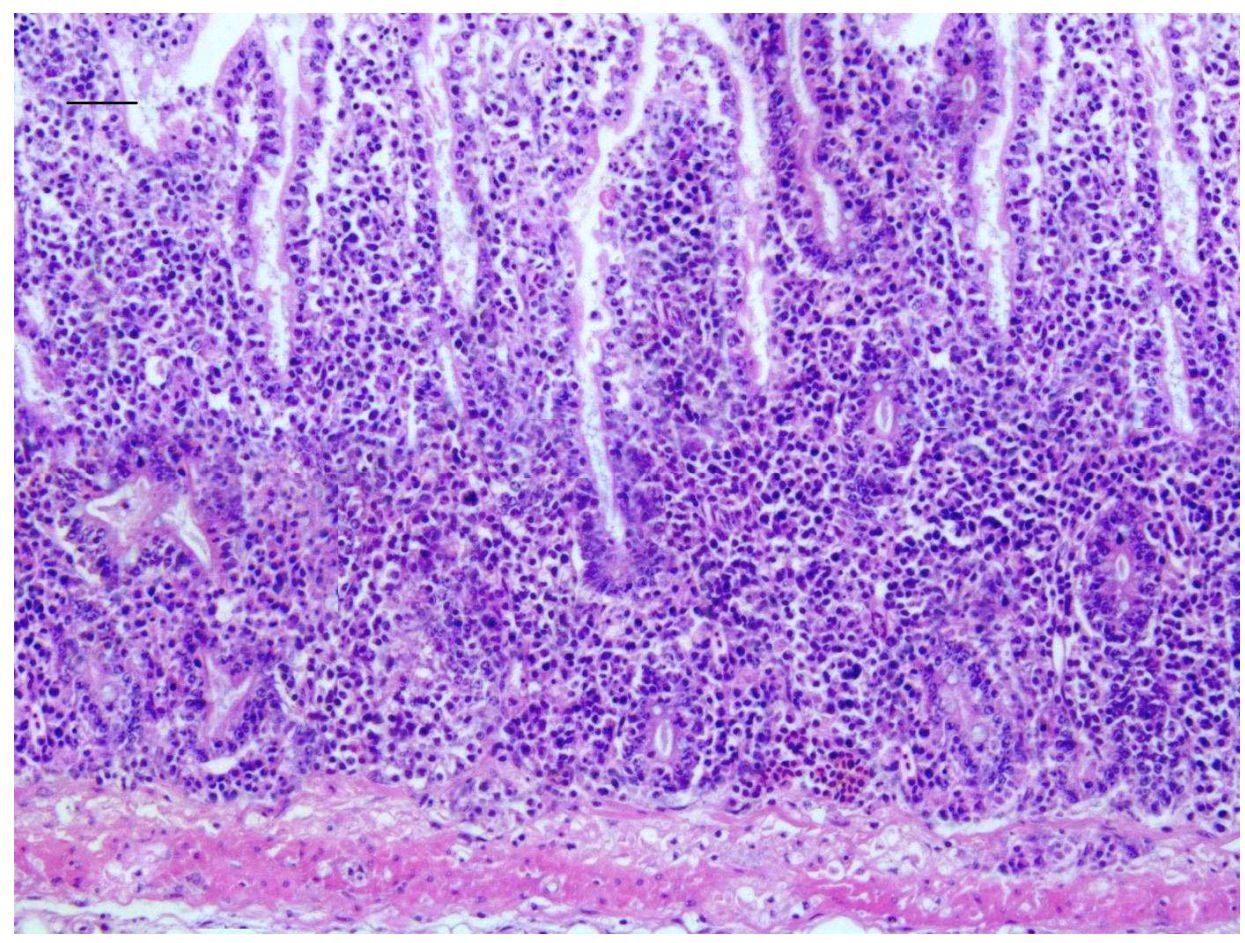

Fig. 2: Second half of the small intestine infected by Eimeria legionensis: severe displacement of the deep crypts, (HE, 20X). Scale bar: $500 \mu \mathrm{m}$ 


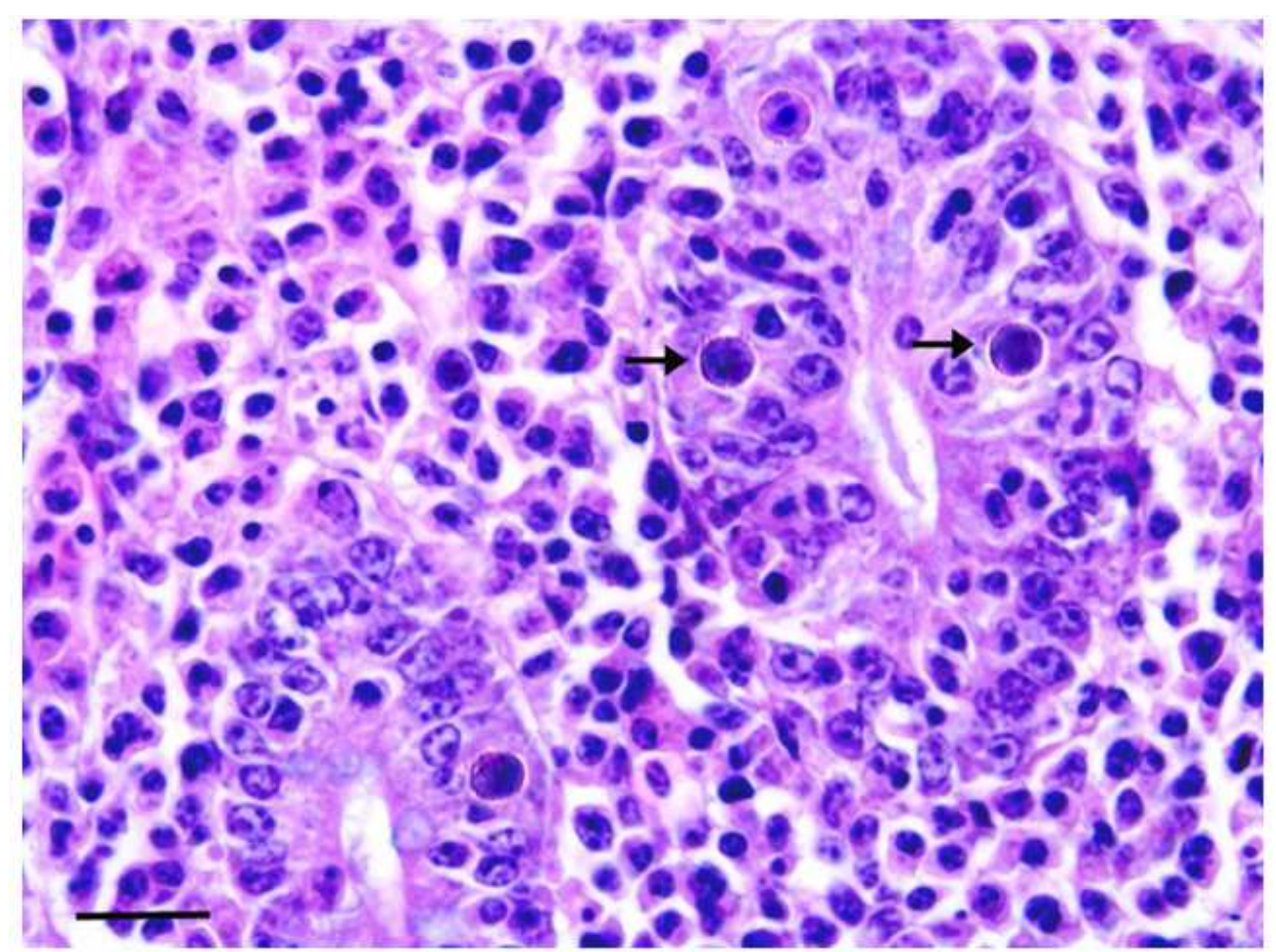

Fig. 3: Terminal portion of the small intestine: intraepithelial Eimeria kofoidi macrogamonts localised between the basal pole and the nucleus of the infected host cells, (HE, 100X). Scale bar: $50 \mu \mathrm{m}$

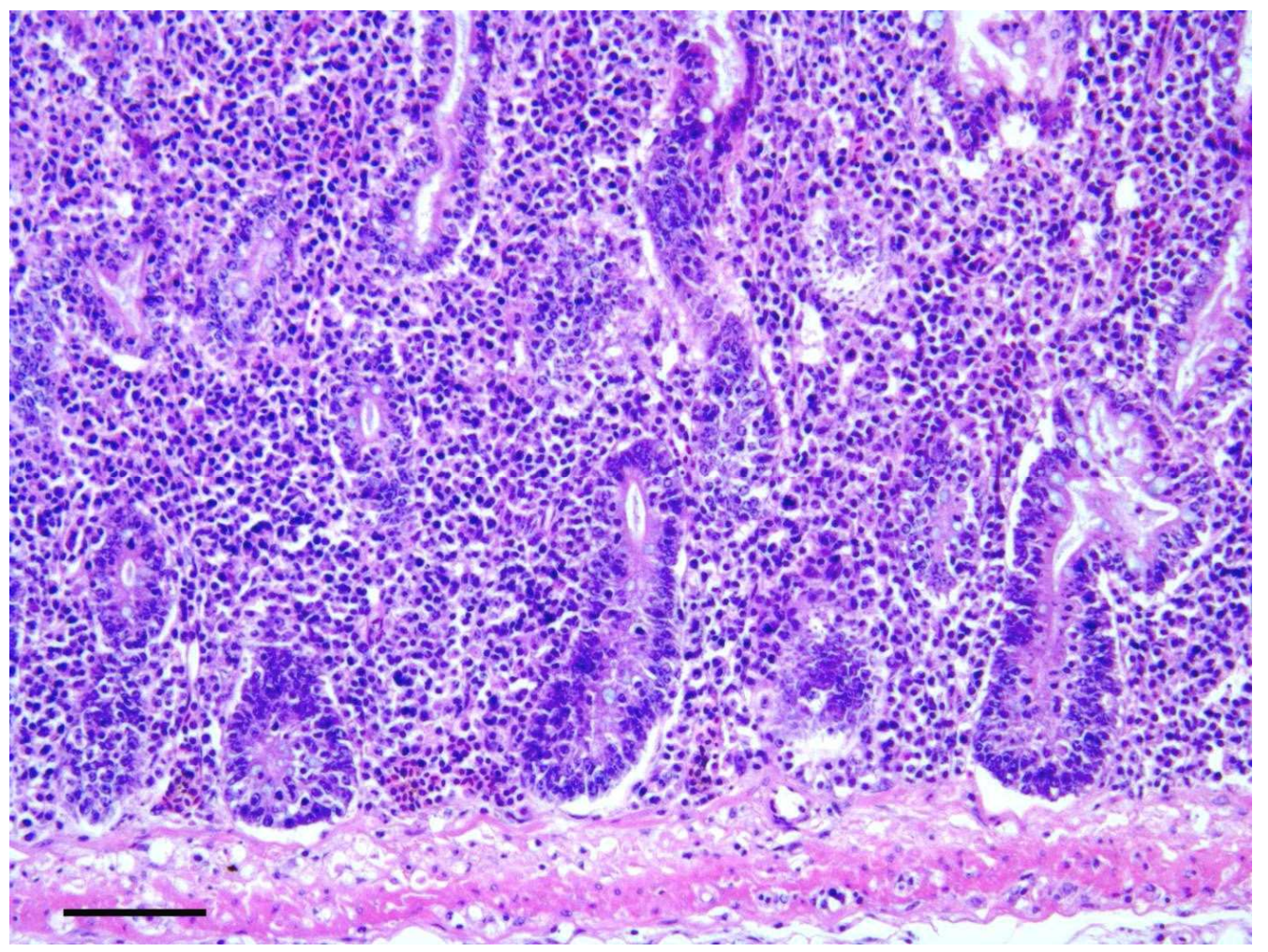

Fig. 4: Transmural infiltration of mononuclear cells in the caecum, (HE, 20X). Scale bar: $500 \mu \mathrm{m}$ 


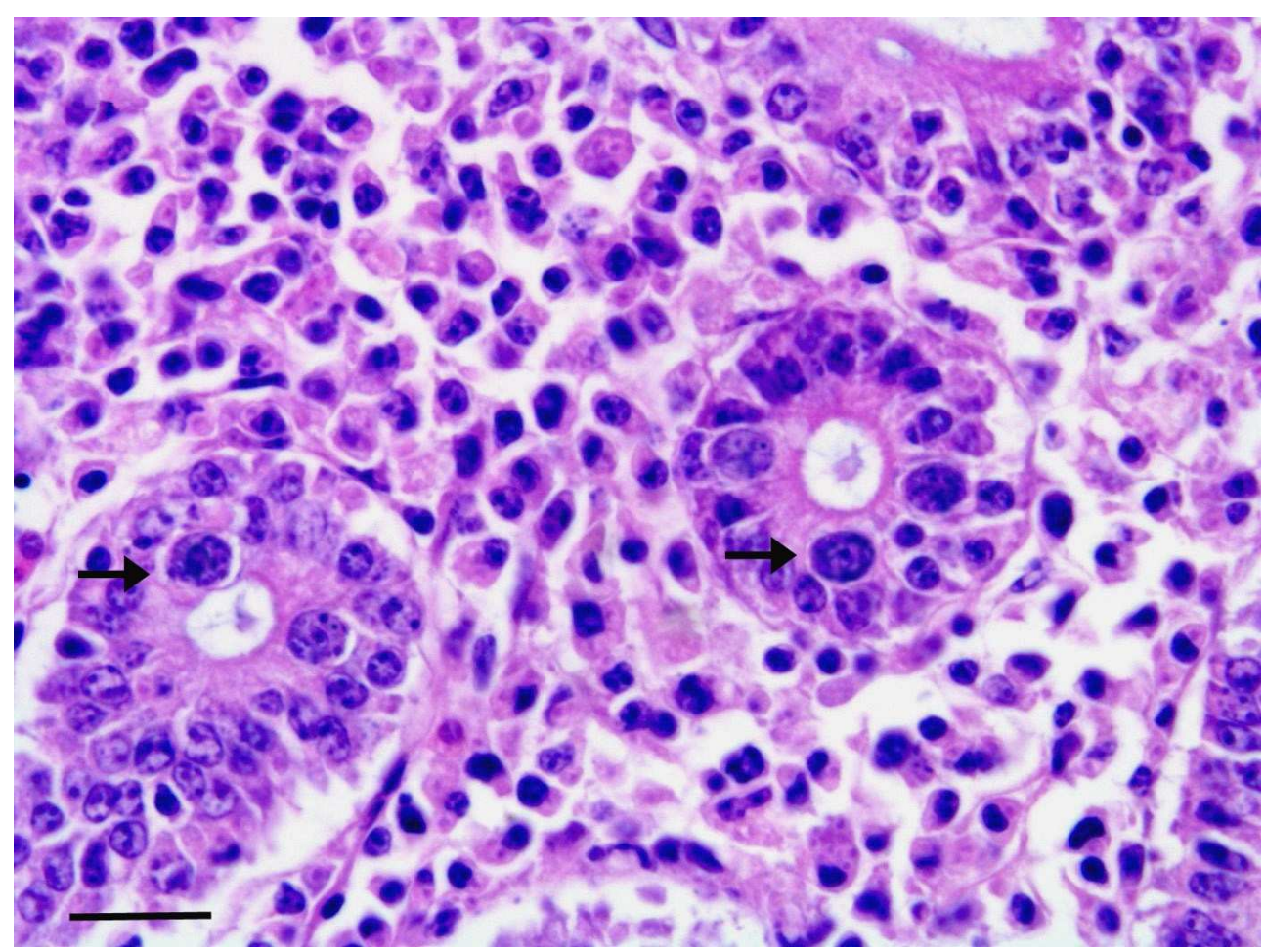

Fig. 5: Caecal mucosa: intraepithelial Eimeria legionensis macrogamonts localised between the nucleus and the free pole of the host cells, (HE, 100X). Scale bar: $50 \mu \mathrm{m}$

Table 3: Range and the mean lesion score values found in the different tracts of the small and the large intestines taken by deceased red-legged partridges (Alectoris rufa) found infected by Eimeria kofoidi and Eimeria legionensis

\begin{tabular}{|c|c|c|c|c|c|c|c|c|c|c|}
\hline \multirow[b]{2}{*}{ Sample } & \multicolumn{5}{|c|}{ Infection score* } & \multicolumn{5}{|c|}{ Lesion score** } \\
\hline & Duodenum & Jejunum & Ileum & Caecum & Colon & Duodenum & Jejunum & Ileum & Caecum & Colon \\
\hline 1 & 0 & 2 & 3 & 3 & 2 & 0 & 2 & 3 & 4 & 1 \\
\hline 2 & 0 & 1 & 3 & 2 & 1 & 0 & 1 & 4 & 4 & 0 \\
\hline 3 & 0 & 1 & 3 & 3 & 2 & 0 & 0 & 3 & 3 & 1 \\
\hline 4 & 0 & 1 & 3 & 3 & 2 & 0 & 2 & 3 & 3 & 1 \\
\hline 5 & 0 & 1 & 3 & 3 & 2 & 0 & 1 & 4 & 4 & 1 \\
\hline 6 & 0 & 1 & 3 & 2 & 2 & 0 & 2 & 4 & 4 & 1 \\
\hline 7 & 0 & 2 & 3 & 3 & 2 & 0 & 1 & 3 & 3 & 1 \\
\hline 8 & 0 & 1 & 3 & 3 & 2 & 0 & 0 & 3 & 4 & 1 \\
\hline 9 & 0 & 1 & 3 & 2 & 1 & 0 & 2 & 4 & 3 & 0 \\
\hline 10 & 0 & 1 & 3 & 3 & 2 & 0 & 1 & 3 & 4 & 1 \\
\hline 11 & 0 & 2 & 3 & 3 & 2 & 0 & 0 & 4 & 4 & 1 \\
\hline 12 & 0 & 1 & 3 & 3 & 2 & 0 & 3 & 4 & 3 & 0 \\
\hline 13 & 0 & 1 & 3 & 3 & 2 & 0 & 2 & 3 & 4 & 1 \\
\hline 14 & 0 & 2 & 3 & 3 & 2 & 0 & 1 & 3 & 3 & 1 \\
\hline 15 & 0 & 2 & 3 & 3 & 2 & 0 & 0 & 3 & 3 & 1 \\
\hline 16 & 0 & 1 & 3 & 3 & 2 & 0 & 2 & 4 & 4 & 1 \\
\hline 17 & 0 & 1 & 3 & 2 & 1 & 0 & 1 & 3 & 3 & 0 \\
\hline 18 & 0 & 1 & 3 & 3 & 2 & 0 & 0 & 3 & 4 & 1 \\
\hline 19 & 0 & 2 & 3 & 3 & 2 & 0 & 0 & 3 & 3 & 1 \\
\hline 20 & 0 & 1 & 3 & 3 & 2 & 0 & 2 & 3 & 4 & 1 \\
\hline 21 & 0 & 2 & 3 & 3 & 2 & 0 & 2 & 4 & 3 & 1 \\
\hline 22 & 0 & 1 & 3 & 2 & 1 & 0 & 1 & 3 & 4 & 0 \\
\hline 23 & 0 & 2 & 3 & 3 & 2 & 0 & 2 & 4 & 4 & 1 \\
\hline 24 & 0 & 1 & 3 & 2 & 2 & 0 & 1 & 4 & 4 & 1 \\
\hline
\end{tabular}




\begin{tabular}{|c|c|c|c|c|c|c|c|c|c|c|}
\hline 25 & 0 & 1 & 3 & 3 & 2 & 0 & 0 & 3 & 3 & 1 \\
\hline 26 & 0 & 1 & 3 & 2 & 1 & 0 & 1 & 3 & 4 & 0 \\
\hline 27 & 0 & 1 & 3 & 3 & 2 & 0 & 2 & 4 & 3 & 1 \\
\hline 28 & 0 & 2 & 3 & 3 & 2 & 0 & 1 & 3 & 4 & 1 \\
\hline 29 & 0 & 1 & 3 & 2 & 2 & 0 & 2 & 4 & 4 & 1 \\
\hline 30 & 0 & 2 & 3 & 3 & 2 & 0 & 2 & 4 & 3 & 1 \\
\hline 31 & 0 & 1 & 3 & 3 & 1 & 0 & 1 & 3 & 4 & 0 \\
\hline 32 & 0 & 2 & 3 & 3 & 2 & 0 & 2 & 3 & 4 & 1 \\
\hline 33 & 0 & 1 & 3 & 3 & 2 & 0 & 1 & 4 & 4 & 1 \\
\hline 34 & 0 & 2 & 3 & 3 & 2 & 0 & 2 & 3 & 3 & 1 \\
\hline 35 & 0 & 1 & 3 & 3 & 1 & 0 & 1 & 3 & 4 & 0 \\
\hline 36 & 0 & 2 & 3 & 3 & 2 & 0 & 1 & 4 & 4 & 1 \\
\hline 37 & 0 & 2 & 3 & 3 & 2 & 0 & 1 & 4 & 4 & 1 \\
\hline 38 & 0 & 1 & 3 & 3 & 2 & 0 & 0 & 4 & 4 & 1 \\
\hline 39 & 0 & 2 & 3 & 3 & 2 & 0 & 1 & 3 & 4 & 1 \\
\hline 40 & 0 & 1 & 3 & 2 & 1 & 0 & 2 & 4 & 4 & 0 \\
\hline 41 & 0 & 2 & 3 & 3 & 2 & 0 & 1 & 3 & 3 & 1 \\
\hline 42 & 0 & 1 & 3 & 3 & 2 & 0 & 0 & 3 & 3 & 1 \\
\hline 43 & 0 & 2 & 3 & 3 & 1 & 0 & 1 & 4 & 3 & 1 \\
\hline 44 & 0 & 2 & 3 & 3 & 2 & 0 & 1 & 3 & 3 & 1 \\
\hline 45 & 0 & 2 & 3 & 2 & 2 & 0 & 1 & 3 & 3 & 1 \\
\hline 46 & 0 & 1 & 3 & 3 & 1 & 0 & 1 & 3 & 4 & 0 \\
\hline 47 & 0 & 1 & 3 & 3 & 2 & 0 & 2 & 4 & 3 & 1 \\
\hline 48 & 0 & 2 & 3 & 3 & 2 & 0 & 1 & 3 & 4 & 1 \\
\hline 49 & 0 & 1 & 3 & 3 & 2 & 0 & 1 & 3 & 4 & 1 \\
\hline 50 & 0 & 2 & 3 & 3 & 2 & 0 & 1 & 4 & 3 & 1 \\
\hline Mean & 0.0 & 1.4 & 3.0 & 2.8 & 1.8 & 0.0 & 1.2 & 3.4 & 3.6 & 0.8 \\
\hline SD* & $\mathbf{0}$ & 0.50 & 0.00 & 0.40 & 0.40 & 0.00 & 0.75 & 0.50 & 0.50 & 0.40 \\
\hline
\end{tabular}

*SD: Standard Deviation

\section{Discussion}

Among the several coccidian species described in the genus Alectoris, including A. rufa, E. legionensis and E. kofoidi have been frequently reported as responsible for coccidiosis outbreaks (Pellérdy, 1974; Levine, 1988; Naciri et al., 2011). Also in northern Italy, these two species were reported as the cause of outbreaks of coccidiosis in farmed A. rufa (Bolognesi et al., 2006).

In previous literature, there is a full agreement on E. legionensis oocyst dimensions (Cordero Del Campillo and Pla Hernàndez, 1966; Bolognesi et al., 2006; Naiciri et al., 2011), while this is not the case of E. kofoidi oocysts. Indeed, in the original description by Yakimoff and Matikaschwili (1936) in chukka partridges (Alectoris chukar) and grey partridges (Perdix perdix), the average size of E. kofoidi oocysts is of $20 \times 17.6 \mu \mathrm{m}$. However, as in the present study, smaller mean dimensions have been reported for $E$. kofoidi oocysts in A. rufa (Lizcano Herrera and Romero Rodriguez, 1972; Bolognesi et al., 2006; Naciri et al., 2011).

Results from the gross and histopathological examination of the intestines are indicative that $E$. kofoidi and E. legionensis coccidiosis was the main cause for the death of the 50 red-legged partridges examined in this study, confirming the epidemic-like coccidiosis outbreaks with considerable mortality previously reported in this bird species (Bolognesi et al., 2006; Naciri et al., 2011). Indeed, the severity of gross and histopathological lesions found in this study in infected intestinal segments are similar to histopathological lesions described in other galliform birds infected by coccidia (Long, 1973; Conway et al., 1990). In particular, in these previous reports clinical coccidiosis has been found associated with thickened intestinal wall, loss of epithelial tissues and villi, necrosis, edema and erosion of the sub-mucosa, glandular tissue cells infiltration, decreased villar height and marked hyperplasia of lymphoid cells. Mononuclear cells infiltration in the intestinal mucosa was a salient finding in intestinal coccidiosis by Emeria garnhami in Coturnix coturnix (Rasheda and Bano, 1985).

In previous studies, some disagreements are also present with regard to the localisation of E. kofoidi and E. legionensis. In particular, in the redlegged partridge $E$. kofoidi was found located in the terminal portion of ileum and in the caecum by Litzcano Herrera and Romero Rodriguez (1972) and in the small intestine, mainly in the duodenal loop and jejunum but also in ileum, by Naciri et al. (2011). In the deceased red-legged partridges here examined, E. kofoidi was found localised 
in the jejunum and ileum both at parasitological and histological analysis, and nor the duodenum nor the caecum were found infected. E. legionensis was described for the first time in Spain in A. rufa and it was considered responsible for caecal infections (Cordero del Campillo and Pla-Hernandez, 1966). This same localisation for E. legionensis, has been recently reported by Naciri et al. (2011). However, data from these previous studies are not based on histopathological analysis of infected intestinal segments.

Histological and morphological analysis, here reported, evidenced that E. kofoidi infect the small intestine, i.e. jejunal and ileal segments, while $E$. legionensis localises in the caecum and colon. In addition, findings from this study showed that $E$. kofoidi macrogamonts are localised between the basal pole and the nucleus of infected cells and this particular localization contributed to nuclear displacement. Macrogamonts of E. legionensis are instead found between the nucleus and the free pole of the host cells. In Eimeria infected red-legged partridges, morphological oocysts examination supported by the evaluation of gross lesions and by the different localisation in the intestine are considered helpful tools for species identification (Naciri et al., 2011).

Gross and histopathological lesions here found in $E$. kofoidi and E. legionensis infected birds may explain the weight loss, the poor feed conversion and the high mortality reported for partridge coccidiosis in previous studies (Reck and McQuistion, 1994; Bolognesi et al., 2006; Naciri et al., 2011), and confirm the frequent involvement of these two Eimeria species in coccidiosis outbreaks of $A$. rufa.

\section{Conclusion}

Results here obtained indicate the colon as a further localisation site of E. legionensis, and provide new data on intestinal lesions and intracellular localisation of $E$. kofoidi and E. legionensis in A. rufa. In particular, findings from this study concerning the different size of E. kofoidi and E. legionensis macrogamonts and their different localisation in the intestine and within the host cells, could give a further help for the differentiation of these two coccidian species in deceased birds.

\section{Author Contributions}

G. Fichi: Partecipated in parasitological analysis and gross examination, contributed to the interpretation of the results, drafting and revision of the manuscript.

G. Rossi: Partecipated in histopathological analysis and contributed to the to the interpretation of the results, drafting and revision of the manuscript.

Stefania Perrucci: Concepted and designed the study, contributed to the acquisition of parasitological data, interpretation of the results, drafting and revision of the manuscript.

\section{Funding}

This research did not receive any specific grant from funding agencies in the public, commercial, or not-for-profit sectors.

\section{Conflict of Interest Statement}

None of the authors has any financial, personal or other associations that may influence the content of the paper.

\section{References}

Birkan, M. and M. Jacob, 1988. La perdix grise. Faune Sauvage. Hatier, Paris, France, pp: 14-70.

Bolognesi, P.G., R. Galuppi, E. Catelli, M. Cecchinato and M. Frasnelli et al., 2006. Outbreak of Eimeria kofoidi and E. legionensis coccidiosis in red-legged partridges (Alectoris rufa). Italian J. Animal Sci., 5: 318-320. DOI: 10.4081/ijas.2006.318

Cordero del Campillo, M. and M. Pla Hernandez, 1966. Sobre las coccidiosis de las perdices, con descripcion de Eimeria legionensis n. sp., parasita de Alectorix rufa L. y una clave para su diferenciacion. Rev. Iber. Parastologia, 26: 27-41.

Conway, D.P., E.M. Mckenzie and A.D. Dayton, 1990. Relationship of coccidial lesion scores and weight gain in infections of Eimeria acervulina, E. maxima and E. tenella in broilers. Avian Pathology, 19: 489-496. DOI: $10.1080 / 03079459008418702$

Duszynski, D.W., L. Couch and S.J. Upton, 2000. The coccidia of galliformes. http://www.kstate.edu/parasitology/worldcoccidia/GALLIFO RMES

Fronte, B., I. Bayram, A.B. Akkaya, G. Rossi and M. Bagliacca, 2013. Effect of corn particle size and inclusion of organic acid in the diet on growth performance and gastrointestinal structure in young chicks. Italian J. Animal Sci., 12 e93: 567-572.

Genta, R.M. and M.F. Dixon, 1995. The Sydney system revisited: The Houston international gastritis workshop. Am. J. Gastroenterol., 90: 1039-41.

Hernandez Rodriguez, S., F. Martinez Gomez and R. Calero Carretero, 1974. Life cycle of coccidia of Spanish partridges. Proceedings of the 3rd International Congress of Parasitology, Vienna: Facta Publication. pp: 95-96.

Levine, N.D., 1988. The protozoan Phylum Apicomplexa. CRC Press, ISBN-10: 0849346533, pp: 356.

Lizcano Herrera, J. and J. Romero Rodriguez, 1972. Contribucion al estudio de las coccipatias del Alectoris rufa (L.). Rev. Iberica de Parastol., 32: 95-113. 
Long, P.L., 1973. Pathology and pathogenicity of coccidial infection. University Park Press, Baltimore, Maryland, pp: 251-94.

Millan, J., 2009. Diseases of the red-legged partridge (Alectoris rufa L.): A review. Wildl. Biol. Pract., 5: 70-88. DOI: $10.2461 /$ wbp.2009.5.2

Naciri, M., J.M. Repérant, G. Fort, J. Crespin and J. Duperray et al., 2011. Eimeria involved in a case of coccidiosis in farmed red-legged partridges (Alectoris rufa) in france: Oocyst isolation and gross lesion description after experimental infection. Avian Pathol., 40: 515-524. DOI: 10.1080/03079457.2011.606798

Pellérdy, L., 1974. Coccidia and Coccidiosis. 2nd Edn. Verlag Paul Parey, ISBN-10: 3489733177, pp: 959.

Perrucci, S., G. Fichi, C. Buggiani, G. Rossi and G. Flamini, 2006. Efficacy of mangiferin against Cryptosporidium parvum in a neonatal mouse model. Parasitol. Res., 99: 184-188.

DOI: $10.1007 / \mathrm{s} 00436-006-0165-4$
Rasheda, M. and L. Bano, 1985. Histopathology of coccidiosis by Emeria garnhami in Coturnix coturnix of N.W.F.P. Pakistan Vet. J., 1: 27-9.

Reck, M. and T.E. McQuistion, 1994. The anticoccidial effects of amprolium, monesin and sodium sulfamethazine in farm-reared chukar partridges (Alectoris graeca) in Illinois. Trans. Illinois State Accademy Sci., 87: 51-59.

Rossi, G., M. Cerquetella, G. Pengo, S. Mari and E. Balint et al., 2015. Immunohistochemical expression of ornithine decarboxylase, diamine oxidase, putrescine, and spermine in normal canine enterocolic mucosa, in chronic colitis and in colorectal cancer. Biomed Res Int., 2015: 172756. DOI: $10.1155 / 2015 / 172756$

Yakimoff, W.L. and I.L. Matikaschwili, 1936. Coccidiosis of the grey and stone partridge. Parasitology, 28: 146-147.

DOI: $10.1017 / \mathrm{S} 0031182000022320$ 